This Journal is available in Telkom University online Journals

Jurnal Manajemen Indonesia

\title{
Conducting Job Analysis for University Student Ambassador and Peer Mentor
}

Andhika Alexander Repi ${ }^{1}$

${ }^{1}$ Fakultas Psikologi, Universitas Katolik Widya Mandala Surabaya, Surabaya, Indonesia

\begin{abstract}
Student Ambassador and Peer Mentor are two positions, which play important role for university. Student Ambassador play role in providing information for prospective student and help new arrivals student settle in, also make the most out of their time while at University, while Peer Mentor help the student to develop student's academic track record. Both of this position must clearly know and understanding their job, tasks and responsibilities. In fact, an overload and overlapping job was experience by these two positions. Unclear and miss understanding about job and role became a root-problem. The purpose of this research is to design and analyse the job of Student Ambassador and Peer Mentor. Qualitatives used as a research method with questioner, interview, and documentation study were adopted as a collecting data method. The participants of this research are the jobholder and the supervisor of Student Ambassador and Peer Mentor. Research result is job analysis document for Student Ambassador and Peer Mentor provided and it consists of job description and job specification. Document of Student Ambassador and Peer Mentor Job Analysis has been approved the university. For future direction, effectiveness of job analysis and it relation with Student Ambassador and Peer Mentor performance must be research. Job analysis based on competences could be a suggestion for further work.
\end{abstract}

Keywords-Job Analysis; Job Description; Job Specification; Human Resources Management Student Ambassador; Peer-Mentor Program

\begin{abstract}
Abstrak
Duta Mahasiswa dan Peer Mentor adalah dua posisi yang berperan penting bagi universitas. Duta Mahasiswa berperan dalam memberikan informasi bagi calon mahasiswa dan membantu mahasiswa pendatang baru beradaptasi, juga memanfaatkan waktu mereka semaksimal mungkin selama di Universitas, sementara Peer Mentor membantu mahasiswa untuk mengembangkan rekam jejak akademik mahasiswa. Kedua posisi ini harus mengetahui dan memahami dengan jelas pekerjaan, tugas dan tanggung jawabnya. Faktanya, pekerjaan yang kelebihan beban dan tumpang tindih dialami oleh kedua posisi ini. Ketidakjelasan dan ketidaktahuan tentang pekerjaan dan peran menjadi akar masalah. Tujuan dari penelitian ini adalah merancang dan menganalisis pekerjaan Duta Mahasiswa dan Peer Mentor. Metode kualitatif yang digunakan sebagai metode penelitian dengan kuisioner, wawancara, dan studi dokumentasi digunakan sebagai metode pengumpulan data. Partisipan dalam penelitian ini adalah jobholder dan supervisor dari Student Ambassador dan Peer Mentor. Hasil penelitian berupa dokumen job analysis untuk Student Ambassador dan Peer Mentor yang disediakan yang terdiri dari job description dan job spesifikasi. Dokumen Analisis Pekerjaan Duta Mahasiswa dan Peer Mentor telah disetujui universitas. Untuk arah kedepan, efektifitas analisa pekerjaan dan kaitannya dengan kinerja Duta Mahasiswa dan Peer Mentor harus diteliti. Analisis pekerjaan berdasarkan kompetensi dapat menjadi saran untuk pekerjaan selanjutnya.
\end{abstract}

Kata kunci-Analisis Pekerjaan; Uraian Tugas; Spesifikasi pekerjaan; Duta Mahasiswa Manajemen Sumber Daya Manusia; Program Peer-Mentor 


\section{INTRODUCTION}

Human resources management is become of the most important program in order to design an effective and efficient performance from the members of organisation. The first step of human resources management is how to design the job by analysis it. Job analysis known as a systematic activity to determine the tasks, duties, and responsibilities needed for each job in organisation. Dessler (2011) define the job analysis as a systematic procedur for determining responsibility and the skill requirements required from jobs and types of people that must be employed for do some work. Bangun (2012) added that on this activity, qualification and specification also collected to know how do some job. Job analysis is very important for organization because it's a basic of human resources development (McKillip, 2001; Mathis \& Jackson, 2006; Truxillo, Paronto, Collins \& Sulzer, 2004; Siddique, 2004; Suthar, 2014). Job analysis will relate to all organisation development programs such as recruitment and selection, performance appraisal, training and development, up to compensation and benefit program.

Job analysis is one of important program and very necessary for human resources management. Mondy (2010) stated that job analysis is necessary if an organization renew their organization structure or add some division. MačKayová, ZáVadská \& Sirotiaková (2010) also explained that, job analysis is needed, when a new job is generated, and also to update jobs. However, job analysis is need if an organization experiences various issues marked with symptoms such as overlapping job, unclear workflow, or even overload job (McKillip, 2001; Cascio, 2003; Ali \& Aroosiya, 2010; Nyasha, et al, 2013; Suthar, et all, 2014). If an organisation does not know the component in job analysis, it will not be able to determine who is employed and how to do it, as well as who is employed or how to train them (Bangun, 2012).

The job analysis consists of job description and job specification (Bratton \& Gold, 1999; Pilbeam \& Corbridge, 2006; Prien, Prien \& Wooten, 2003). Job description is a written statement that explains the duties, the responsibility, and key performance indicator. Mathis and Jackson (2006) implied that job description contains an outline of the roles and responsibilities of the job. Simplify, job description defines as what a job is and what the task-holder will do at the organisation. The othet component of job analysis is called as job specifications. It is describes the human characteristics needed by the person performing the job. Job specifications contain characteristics that must be owned by the holder of office (Cook, 2005; Dessler, 2006). These characteristics include experiences, sex, education, training, the abily to meet physical either mental demands. Simplify, job specifications is a list of requirement on one job title.

University WM is a private university at Surabaya. It consists of 20-study program. On of the program on this university are Student Ambassador and Peer Mentor. The Student Ambassador aim are serving and representing University WM. They will meet many new peoples such as prospective students and their parents, encourages others to get involved in University WM, answer any questions about University WM, ensuring the new arrivals student settle in, and make the most out of their time while at University. The other hand, Peer Mentor program is important program for the student. The function and role for this program which senior student must be a mentor and help for their junior student.

By the preliminary research, researcher find that the Student Ambassador and Peer Mentor haven't perform optimal oh their work. Overlap responsibilities between Student Ambassador each other the Peer Mentor do not yet have a complete understanding of their duties, responsibilities and role as mentors. Nyasha, et al (2013) states that the lack of clarity and lack of understanding of the role of a job cause the performance of the stakeholders is not optimal. Boulanger (2013) also found that the uncertainty of a job would create a decrease in job satisfaction, slow the tempo of work, and even will increase work-stress. The non-optimal performance both of the Student Ambassador and Peer Mentor demonstrated through overloading and overlapping of work, delays when it comes to meetings, and delays in task submissions.

Fountain \& Newcomer (2016) states that in order to develop a successful and sustained some program in organisation, there needs to provided by clear and detailed guidance about what is their job and role. In order to make clear and detailed guidance about peer mentor job description and role, job analysis must be conducted. Meanwhile, the University WM has not yet conduct job analysis for the Student Ambassador and Peer Mentor

Based on the research background above, researcher would like to do the research about job analysis and job design. Limitations in this study is job analysis and job design on Student Ambassador and Peer Mentor at University WM. The purpose of this research is to design and analyse the job of Student Ambassador and Peer Mentor 


\section{LITERATURE REVIEW}

\section{A. Job Analysis Definition}

Many research has defined what job analysis is. Accordingly Brannick et al. (2007), job description is set of document consist of job description to make members of organization understand clearly, accurately and specifically, also to perform their jobs well. Armstrong (2009) defined job analysis as a process of collecting, analysing, and setting out information about the contents of jobs in order to provide the basic job description and job specification. As mentioned by Raju \& Banerjee (2017), job analysis is a process of determining the task that make up the job, skills, abilities, and responsibilities required for the job's holder.

Another researcher said, job analysis consists of collecting data to produce job description, job specifications, and job standards (Bratton and Gold, 2007). Therefore, a job description, job specification, and job standards are result of a job analysis (Mangaleswaran \& Kirushanthan, 2015). MačKayová, ZáVadská \& Sirotiaková (2010) stated that, job analysis must provides all necessary information relating with job which are crititcal to work out tasks' profiles, duties, responsibilities, criteria of job holder, and their roles.

By those definition, job analysis will explained as a systematic process consist of collecting-analysingsetting out information about job description, job specification, and job standards on some job-title to prevent misunderstand and unclear role between job's holder. The operational definition of job analysis on this research is a procedure for determining duties, job description, job specification of a Student Ambassador and Peer Mentor to avoid overload and overlapping job. The result of the job analysis on this research is Student Ambassador and Peer Mentor job description and job specification document.

\section{B. Purpose \& Importance of Job Analysis}

The purpose of job analysis is to establish and document about what some job-title must do. Important to be remembering, job analysis is conducted of the job, not the job's holder. The product of the job analysis is a description and specifications of the job, not a description or specification of the job's holder (I-Wei \& Kleiner, 2002; Kharabe \& Joseph, 2016).

Job analysis is the basic and foundation for many functions of human resources (Cascio, 1998; Bowin \& Harvey, 2000; Dessler, 2006). Job analysis through job description and job specification are important to implement other human resource management activities, such as recruitment \& selection process, training and development, performance appraisal, design of compensation \& benefit system, etc (McKillip, 2001; Mathis \& Jackson, 2004; Truxillo, Paronto; Siddique, 2004; MačKayová, ZáVadská \& Sirotiaková, 2010; Suthar, 2014; Mangaleswaran \& Kirushanthan, 2015; Levine, Sistrunk, McNutt \& Gael cited by Raju \& Banerjee, 2017). Job analysis is playing vital role in any strategic step in organization (I-Wei \& Kleiner, 2002; Edien, 2015). Simply to say, job analysis is directly related to nearly every function of human resource departments in organizations.

Well developed job analysis document is needed to clear all the obstacle such as, overlapping \& overload work, that members of organization will faced while performing their tasks and duties (Royer, 2009). Welldesigned job analysis prevents unnecessary misunderstanding while members of organization doing their job (Mckillip, 2001; Mathis \& Jackson, 2004; Raju \& Banerjee, 2017). It also can be used in performance review of organization members in order to develop goals / objectives, standard performance, criteria evaluation, and duties to be evaluated (Kharabe \& Joseph, 2006).

The importance of Student Ambassador and Peer Mentor job analysis is to provide the jobholder with clear, accurately, and specifically job analysis document. This document could prevent misunderstanding, overload and overlapping job and role between the jobholders. 


\begin{tabular}{|c|c|c|c|}
\hline Planning A Preparation & Analyzing the toh & 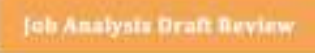 & $\begin{array}{c}\text { Joh Anatyato Documint } \\
\text { Vadidation }\end{array}$ \\
\hline $\begin{array}{l}\text { Ask permission to the } \\
\text { institution } \\
\text { Determine the method of } \\
\text { job analysis } \\
\text { Determine and prepare } \\
\text { the template of job } \\
\text { analysis (print and } \\
\text { duplicate the template) } \\
\text { - Determine the ideal of } \\
\text { fob description and job } \\
\text { speeiflcation of related } \\
\text { job } \\
\text { Contact the respondents } \\
\text { in the job analysis } \\
\text { process }\end{array}$ & $\begin{array}{l}\text { - Intake data through } \\
\text { method that had been } \\
\text { determined on the first } \\
\text { stage } \\
\text { - Analyze the result of } \\
\text { intake data } \\
\text { - Make job analysis draft } \\
\text { (input the data which has } \\
\text { been analyzed into job } \\
\text { analysis draft template) }\end{array}$ & $\begin{array}{l}\text { Distribute the job } \\
\text { analysis draft to related } \\
\text { person for review. This } \\
\text { review aims to ensure } \\
\text { that the contents on job } \\
\text { analysis draft fit the ideal } \\
\text { Job } \\
\text { description/specification } \\
\text { - If there any correction or } \\
\text { revision of the draft } \\
\text { contents, the reviewer } \\
\text { may directly insert it } \\
\text { within the draft } \\
\text { Analyst revise the draft } \\
\text { - This process is carried } \\
\text { out continuously until } \\
\text { the reviewers approve } \\
\text { the draft. }\end{array}$ & $\begin{array}{l}\text { The signature into the } \\
\text { document from } \\
\text { stakeholders } \\
\text { representatives indicates } \\
\text { the validation of job } \\
\text { analysis document. } \\
\text { - Approved job analysis } \\
\text { document will be } \\
\text { printed, copied, and } \\
\text { distributed to } \\
\text { stakeholders } \\
\text { representatives } \\
\text { Valid job analysis } \\
\text { document will socialize } \\
\text { to all members of } \\
\text { organization }\end{array}$ \\
\hline
\end{tabular}

Figure 1. Job Analysis Process by Mathis \& Jackson (2006)

In traditional approach, job analysis process is dividing into four basic phases: (1) Planning period; (2) Preparation period; (3) Execution period; (4) Assessment period (. Meanwhile, Mathis \& Jackson (2006) listed 4 stages of job analysis process as below:

\section{RESEARCH Methodology}

In this research, researcher used types qualitatives research with purpose to systemactically and accurately describing facts and characteristics regarding population or fields certain, which is about job analysis in an organisation. Sources of data in this study are using primary data and secondary data. The primary data is data obtained directly from research subjects by using an instrument such as questioner and an interview. While secondary data obtained indirectly from the journal, organisation structure, organisation document, report and books related with the topic of research.

Collecting data methods were using questionnaire and interview. The questionnaire was used to obtain basic data from the jobholder and stakeholders. Meanwhile, interviews are used to sharpen and confirm data on the results of the questionnaire. In order to check the validity and consistency of research, triangulation examination technique and criteria of credibility was used. The procedure of the research was based on the process of job analysis from Mathis and Jackson (2006). They implied that job analysis is a systematic procedure that consists with four stages: (1) Planning \& preparation; (2) analyzing the job; (3) job analysis draft review; and (4) job analysis document validation. For ethical approval, the institutional review board University WM of Surabaya approved this job analysis document.

\section{RESUlt AND DisCUSSION}

In this study there are 10 positions that analysed, which are: Student Ambassador called Duta WM. Duta WM is consists of 9 organisation job title. All the 9 job title already analysed on this research. The 9 job title of Duta WM as Student Ambassdor are (1) PIC Duta WM; (2) Koordinator Seksi Wilayah Duta WM; (3) Anggota Seksi Wilayah Duta WM; (4) Koordinator Seksi Acara Duta WM; (5) Anggota Seksi Acara Duta WM; (6) Koordinator Media Sosial Duta WM; (7) Anggota Media Sosial Duta WM; (8) Koordinator Seksi Publikasi dan Dokumentasi Duta WM; and (9) Anggota Seksi Publikasi dan Dokumentasi Duta WM and the Peer Mentor. The job title was analysed by using job analysis stages from Mathis \& Jackson (2006). 
The following are the results of analysis and design work done:

\section{A. PIC Duta WM}

The responsibility of PIC Duta WM is for controlling all ambassador division and bridging between Duta WM and the Head of Promotion University WM. The job description of PIC Duta WM are (1) Participate in all Promotion activities such as Expo, Presentation, Solo Exhibition, High School Visit, Photo Brochure, Parents Gathering, and other University Events; (2) Answering all questions related to student admission/enrollment, Study Program and University, both directly and indirectly; (3) Establish communication with Guidance and Counselling Teachers in all High Schools Collaboration in providing information about student admission / enrolment, Study Programs and Universities; (4) Help prepare all the equipment for promotional activities, such as organizing luggage, preparing brochures, souvenirs, roll banners, backdrops and all other accessories; (5) Representing the promotion team in coordination with high schools, attending Technical Meetings and structuring stands in the field related to all promotional activities; (6) Attend shifts, routine meetings and training according to a predetermined schedule; (7) Update the latest information of each study program, both regarding student admission / enrolment, achievements, competitions, special events to the Head of Promotion Affairs, and Seksi Wilayah every 3 months; (8) Coordinate with the Koordinator Seksi Wilayah in putting together a promotion team in the field; (9) Coordinate among the Duta WM Section when organizing a promotional activity; (10) Coordinate the preparation of guard shift Duta WM in Student Admission / Enrolment Department during the first meeting every 1 semester; (11) Arrange the agenda, materials and plans for the date of the meeting activities for 1 semester; (12) Summarize the timeline of each activities Duta WM for 1 semester; (13) Control the timeline of activities for each division Duta WM for 1 semester; (14) Coordinating Duta WM in developing upcoming promotional concepts (brochures, souvenirs, etc.) each year (15) Lead a routine coordination meeting every 2 months with the Koordinator to evaluate the progress of the Duta WM; (16) Lead a routine coordination meeting every 3 months with all Duta WM to evaluate the progress of the Duta WM; (17) Report to the Head of Promotion of University WM every 1 semester.

The job specifications for PIC Duta WM are fluent communication oral and written, perform well service excellent, responsive, perform team-leadership, and perform good decision-making. For the requirement are all student who study at University WM with second year, GPA > 3.00 of 4.00, and ever experience in any organization.

The job description of Koordinator Seksi Wilayah Duta WM are (1) Participate in all Promotion activities such as Expo, Presentation, Solo Exhibition, High School Visit, Photo Brochure, Parents Gathering, and other University Events; (2) Answering all questions related to student admission/enrollment, Study Program and University, both directly and indirectly; (3) Establish communication with Counselling Teachers in all High Schools Collaboration in providing information about student admission / enrolment, Study Programs and Universities; (4) Help prepare all the equipment for promotional activities, such as organizing luggage, preparing brochures, souvenirs, roll banners, backdrops and all other accessories; (5) Representing the promotion team in coordination with high schools, attending Technical Meetings and structuring stands in the field related to all promotional activities; (6) Attend shifts, routine meetings and training according to a predetermined schedule; (7) Update the latest information of each study program, both regarding student admission / enrolment, achievements, competitions, special events to the Head of Promotion Affairs, and PIC Duta WM every 3 months; (8) Coordinate with the Field Coordinators in putting together a promotion team in the field; (9) Coordinate among the Duta WM Section when organizing a promotional activity; (10) Design a work program plan including the timeline of the Duta WM Seksi Wilayah every 1 semester; (11) Coordinate Anggota Seksi Wilayah Duta WM in data collection and updating information relating to student admission / enrolment, achievements (lecturers and students), information about competitions, or special events in all study programs per region to the Head of Promotion Affairs and PIC Duta WM every 3 months; (12) Coordinate the data collection and contact students from each study program per region to participate in promotional activities as needed; (13) Register and contact students from each study program per region to participate in the required promotional activities; (14) Establish communication with each Information Service Team (student admission / enrolment team, Lecturer Team, Duta WM Team, and students) per region in the campus tour activities and photo brochures; (15) Report to the PIC Duta WM every 1 semester.

The job specifications for Koordinator Seksi Wilayah Duta WM are fluent communication oral and written, perform well service excellent, responsive, perform team-leadership, perform good decision-making, and having a wider network. For the requirement are all student who study at University WM with second year, GPA > 3.00 of 4.00, and ever experience in any organization. 


\section{B. Members of the WM Ambassador Regional Section}

Members of the WM Ambassador Regional Section is responsible for managing the information service team in each student admission/enrollment activity in their respective regions. The job description of Anggota Seksi Wilayah Duta WM are (1) Participate in all Promotion activities such as Expo, Presentation, Solo Exhibition, High School Visit, Photo Brochure, Parents Gathering, and other University Events; (2) Answering all questions related to student admission/enrollment, Study Program and University, both directly and indirectly; (3) Establish communication with Guidance and Counselling Teachers in all High Schools Collaboration in providing information about student admission / enrolment, Study Programs and Universities; (4) Help prepare all the equipment for promotional activities, such as organizing luggage, preparing brochures, souvenirs, roll banners, backdrops and all other accessories; (5) Representing the promotion team in coordination with high schools, attending Technical Meetings and structuring stands in the field related to all promotional activities; (6) Attend shifts, routine meetings and training according to a predetermined schedule; (7) Update the latest information of each study program, both regarding student admission / enrolment, achievements, competitions, special events to the Head of Promotion Affairs, and PIC Duta WM every 3 months; (8) Coordinate with the Koordinator Seksi Wilayah Duta WM in putting together a promotion team in the field; (9) Coordinate among the all Duta WM section when organizing a promotional activity; (10) Register and update information relating to student admission/enrolment, achievements (lecturers and students), competition information, or special events in all study programs per region from all Duta WM to the Head of Promotion Affairs and PIC Duta WM every 3 months; (11) Register and contact students from each study program per region to participate in the required promotional activities; (12) Establish communication with each Information Service Team (Student Admission/Enrollment team, Lecturer Team, Duta WM Team, and students) per region in the campus tour activities and photo brochures; (13) Report to the PIC Duta WM every 1 semester.

The job specifications for Anggota Seksi Wilayah Duta WM are fluent communication oral and written, perform well service excellent, responsive, perform good decision-making, and having a wider network. For the requirement are all student who study at University WM with second year, GPA > 3.00 of 4.00, and ever experience in any organization.

\section{Koordinator Seksi Acara Duta WM}

Koordinator Seksi Acara Duta WM is responsible for coordinating every planning, implementation and evaluation of all University WM promotional activities. The job description of Koordinator Seksi Acara Duta WM are (1) Participate in all Promotion activities such as Expo, Presentation, Solo Exhibition, High School Visit, Photo Brochure, Parents Gathering, and other University Events; (2) Answering all questions related to student admission/enrollment, Study Program and University, both directly and indirectly; (3) Establish communication with Guidance and Counselling Teachers in all High Schools Collaboration in providing information about student admission / enrolment, Study Programs and Universities; (4) Help prepare all the equipment for promotional activities, such as organizing luggage, preparing brochures, souvenirs, roll banners, backdrops and all other accessories; (5) Representing the promotion team in coordination with high schools, attending Technical Meetings and structuring stands in the field related to all promotional activities; (6) Attend shifts, routine meetings and training according to a predetermined schedule; (7) Update the latest information of each study program, both regarding student admission / enrolment, achievements, competitions, special events to the Head of Promotion Affairs, and PIC Duta WM every 3 months; (8) Coordinate with the Koordinator Seksi Wilayah Duta WM in putting together a promotion team in the field; (9) Coordinate among the all Duta WM section when organizing a promotional activity; (10) Design a plan of promotional activities including the timeline of the Seksi Acara Duta WM every 1 semester; (11) Develop concept events (including evaluations) and committees for special promotional events, such as Solo Exhibitions, High School Visits, Parents Gathering, and other University Events; (12) Coordinate the implementation of events and committees for special promotional events, such as solo exhibitions, high school visits, parents gathering, and other university events; (13) Develop concepts and timelines of training activities and provision of Information Services for Lecturers and Students for 1 semester; (14) Coordinating training activities and debriefing of Lecturer and Student Information Service Teams for 1 semester, and (15) Report to the PIC Duta WM every 1 semester.

The job specifications for Koordinator Seksi Acara Duta WM are fluent communication oral and written, perform well service excellent, responsive, perform team-leadership, perform good decision-making, and creative. For the requirement are all student who study at University WM with second year, GPA > 3.00 of 4.00, and ever experience in any organization. 


\section{Anggota Seksi Acara Duta WM}

Anggota Seksi Acara Duta WM is responsible for planning, implementation and evaluation of all University WM promotional activities.The job description of Anggota Seksi Acara Duta WM are (1) Participate in all Promotion activities such as Expo, Presentation, Solo Exhibition, High School Visit, Photo Brochure, Parents Gathering, and other University Events; (2) Answering all questions related to student admission/enrollment, Study Program and University, both directly and indirectly; (3) Establish communication with Guidance and Counselling Teachers in all High Schools Collaboration in providing information about student admission / enrolment, Study Programs and Universities; (4) Help prepare all the equipment for promotional activities, such as organizing luggage, preparing brochures, souvenirs, roll banners, backdrops and all other accessories; (5) Representing the promotion team in coordination with high schools, attending Technical Meetings and structuring stands in the field related to all promotional activities; (6) Attend shifts, routine meetings and training according to a predetermined schedule; (7) Update the latest information of each study program, both regarding student admission / enrolment, achievements, competitions, special events to the Head of Promotion Affairs, and PIC Duta WM every 3 months; (8) Coordinate with the Koordinator Seksi Wilayah Duta WM in putting together a promotion team in the field; (9) Coordinate among the all Duta WM section when organizing a promotional activity; (10) Support the Koordinator Seksi Acara Duta WM to design a plan of promotional activities including the timeline of the Seksi Acara Duta WM every 1 semester; (11) Develop concept events (including evaluations) and committees for special promotional events, such as Solo Exhibitions, High School Visits, Parents Gathering, and other University Events; (12) running the implementation of events and committees for special promotional events, such as solo exhibitions, high school visits, parents gathering, and other university events; (13) Support the Koordinator Seksi Acara Duta WM to develop concepts and timelines of training activities and provision of Information Services for Lecturers and Students for 1 semester; (14) Support the Koordinator Seksi Acara Duta WM to coordinate training activities and debriefing of Lecturer and Student Information Service Teams for 1 semester, and (15) Report to the Koordinator Seksi Acara Duta WM every 1 semester.

The job specifications for Koordinator Seksi Acara Duta WM are fluent communication oral and written, perform well service excellent, responsive, perform good decision-making, and creative. For the requirement are all student who study at University WM with second year, GPA > 3.00 of 4.00, and ever experience in any organization.

\section{E. Koordinator Media Sosial Duta WM}

Koordinator Media Sosial Duta WM is responsible for coordinating student admission/enrollment social media management. The job description of Koordinator Media Sosial Duta WM are (1) Participate in all Promotion activities such as Expo, Presentation, Solo Exhibition, High School Visit, Photo Brochure, Parents Gathering, and other University Events; (2) Answering all questions related to student admission/enrollment, Study Program and University, both directly and indirectly; (3) Establish communication with Guidance and Counselling Teachers in all High Schools Collaboration in providing information about student admission / enrolment, Study Programs and Universities; (4) Help prepare all the equipment for promotional activities, such as organizing luggage, preparing brochures, souvenirs, roll banners, backdrops and all other accessories; (5) Representing the promotion team in coordination with high schools, attending Technical Meetings and structuring stands in the field related to all promotional activities; (6) Attend shifts, routine meetings and training according to a predetermined schedule; (7) Update the latest information of each study program, both regarding student admission / enrollment, achievements, competitions, special events to the Head of Promotion Affairs, and PIC Duta WM every 3 months; (8) Coordinate with the Koordinator Seksi Wilayah Duta WM in putting together a promotion team in the field; (9) Coordinate among the all Duta WM section when organizing a promotional activity; (10) Design a plan of promotional activities by social media including the timeline of the Media Sosial Duta WM every 1 semester; (11) Control and update the latest student admission / enrollment information on the wmpmb.com website every week; (12) Coordinate and operate student admission / enrollment official social media, including, arrange timeline for social media content to be run, arrange content, captions and hashtags that are interesting and up-to-date; (13) Coordinate and collect, edit and upload all documentation of promotional activities of all Lecturer and Student Information Service Teams in charge; (14) Answer questions or respond to statements about student admission / enrollment, Study Programs and Universities on student admission / enrollment official social media (Instagram and Facebook); (15) Coordinating the implementation of the 'Duta Njawab' content; (16) Coordinating and interacting (Follow, Like Post, Comments) with social media accounts from high school and social media accounts related to education; (17) Increase traffic and popularity of student admission / enrollment official social media; (18) Report to the PIC Duta WM every 1 semester. 
The job specifications for Koordinator Media Sosial Duta WM are fluent communication oral and written, perform well service excellent, responsive, perform team-leadership, perform good decision-making, creative, and known-well social media operating. For the requirement are all student who study at University WM with second year, GPA > 3.00 of 4.00, and ever experience in any organization.

\section{F. Anggota Media Sosial Duta WM}

Anggota Media Sosial Duta WM is responsible for manage student admission/enrollment social media. The job description of Anggota Media Sosial Duta WM are (1) Participate in all Promotion activities such as Expo, Presentation, Solo Exhibition, High School Visit, Photo Brochure, Parents Gathering, and other University Events; (2) Answering all questions related to student admission/enrollment, Study Program and University, both directly and indirectly; (3) Establish communication with Guidance and Counselling Teachers in all High Schools Collaboration in providing information about student admission / enrolment, Study Programs and Universities; (4) Help prepare all the equipment for promotional activities, such as organizing luggage, preparing brochures, souvenirs, roll banners, backdrops and all other accessories; (5) Representing the promotion team in coordination with high schools, attending Technical Meetings and structuring stands in the field related to all promotional activities; (6) Attend shifts, routine meetings and training according to a predetermined schedule; (7) Update the latest information of each study program, both regarding student admission / enrollment, achievements, competitions, special events to the Head of Promotion Affairs, and PIC Duta WM every 3 months; (8) Coordinate with the Koordinator Seksi Wilayah Duta WM in putting together a promotion team in the field; (9) Coordinate among the all Duta WM section when organizing a promotional activity; (10) Support the Koordinator Media Sosial Duta WM to design a plan of promotional activities by social media including the timeline of the Media Sosial Duta WM every 1 semester; (11) Control and update the latest student admission / enrollment information on the wmpmb.com website every week; (12) Operate student admission / enrollment official social media, including, arrange timeline for social media content to be run, arrange content, captions and hashtags that are interesting and up-to-date; (13) Collect, edit and upload all documentation of promotional activities of all Lecturer and Student Information Service Teams in charge; (14) Answer questions or respond to statements about student admission / enrollment, Study Programs and Universities on student admission / enrollment official social media (Instagram and Facebook); (15) Held the implementation of the 'Duta Njawab' content; (16) Interacting (Follow, Like Post, Comments) with social media accounts from high school and social media accounts related to education; (17) Increase traffic and popularity of student admission / enrollment official social media; (18) Report to the Koordinator Media Sosial Duta WM every 1 semester.

The job specifications for Anggota Media Sosial Duta WM are fluent communication oral and written, perform well service excellent, responsive, perform good decision-making, creative, and known-well social media operating. For the requirement are all student who study at University WM with second year, GPA > 3.00 of 4.00, and ever experience in any organization.

\section{G. Koordinator Seksi Publikasi dan Dokumentasi Duta WM}

Koordinator Seksi Publikasi dan Dokumentasi Duta WM is responsible for coordinating the team regarding the publication and documentation of all activities in the Duta WM program. The job description of Koordinator Seksi Publikasi dan Dokumentasi Duta WM are (1) Participate in all Promotion activities such as Expo, Presentation, Solo Exhibition, High School Visit, Photo Brochure, Parents Gathering, and other University Events; (2) Answering all questions related to student admission/enrollment, Study Program and University, both directly and indirectly; (3) Establish communication with Guidance and Counselling Teachers in all High Schools Collaboration in providing information about student admission / enrolment, Study Programs and Universities; (4) Help prepare all the equipment for promotional activities, such as organizing luggage, preparing brochures, souvenirs, roll banners, backdrops and all other accessories; (5) Representing the promotion team in coordination with high schools, attending Technical Meetings and structuring stands in the field related to all promotional activities; (6) Attend shifts, routine meetings and training according to a predetermined schedule; (7) Update the latest information of each study program, both regarding student admission / enrollment, achievements, competitions, special events to the Head of Promotion Affairs, and PIC Duta WM every 3 months; (8) Coordinate with the Koordinator Seksi Wilayah Duta WM in putting together a promotion team in the field; (9) Coordinate among the all Duta WM section when organizing a promotional activity; (10) Design a plan of promotional activities including the timeline of the Seksi Publikasi dan Dokumentasi Duta WM every 1 semester; (11) Coordinate and design promotional needs for each change of period (backdrop, roll banners, posters); (12) Coordinate and participate in documenting every promotional activity, both photos and videos, and (13) Report to the PIC Duta WM every 1 semester. 
The job specifications for Koordinator Seksi Publikasi dan Dokumentasi Duta WM are fluent communication oral and written, perform well service excellent, responsive, perform good team-leadershiop, perform good decision-making, creative, and known-well graphic-design and photography. For the requirement are all student who study at University WM with second year, GPA > 3.00 of 4.00, and ever experience in any organization.

\section{H. Anggota Seksi Publikasi dan Dokumentasi Duta WM}

Anggota Seksi Publikasi dan Dokumentasi Duta WM is responsible for running regarding the publication and documentation of all activities in the Duta WM program. The job description of Anggota Seksi Publikasi dan Dokumentasi Duta WM are (1) Participate in all Promotion activities such as Expo, Presentation, Solo Exhibition, High School Visit, Photo Brochure, Parents Gathering, and other University Events; (2) Answering all questions related to student admission/enrollment, Study Program and University, both directly and indirectly; (3) Establish communication with Guidance and Counselling Teachers in all High Schools Collaboration in providing information about student admission / enrolment, Study Programs and Universities; (4) Help prepare all the equipment for promotional activities, such as organizing luggage, preparing brochures, souvenirs, roll banners, backdrops and all other accessories; (5) Representing the promotion team in coordination with high schools, attending Technical Meetings and structuring stands in the field related to all promotional activities; (6) Attend shifts, routine meetings and training according to a predetermined schedule; (7) Update the latest information of each study program, both regarding student admission / enrollment, achievements, competitions, special events to the Head of Promotion Affairs, and PIC Duta WM every 3 months; (8) Coordinate with the Koordinator Seksi Wilayah Duta WM in putting together a promotion team in the field; (9) Coordinate among the all Duta WM section when organizing a promotional activity; (10) Support the Design a plan of promotional activities including the timeline of the Seksi Publikasi dan Dokumentasi Duta WM every 1 semester; (11) Coordinate and design promotional needs for each change of period (backdrop, roll banners, posters); (12) Coordinate and participate in documenting every promotional activity, both photos and videos, and (13) Report to the PIC Duta WM every 1 semester.

The job specifications for Koordinator Seksi Publikasi dan Dokumentasi Duta WM are fluent communication oral and written, perform well service excellent, responsive, perform good decision-making, creative, and knownwell graphic-design and photography. For the requirement are all student who study at University WM with second year, GPA > 3.00 of 4.00, and ever experience in any organization.

\section{Peer Mentor}

The main job description of Peer Mentor group by two main functions, are mentoring, and administration. For the mentoring job description is consists of 6 tasks. The first task for the mentor is regularly set up meeting with mentee. Mentors must held at least, mentor-mentee meeting 4 times a month with an agenda (schedule $\&$ topic) will discuss by mentor with mentee, and make report every held a meeting. The second task is to conduct a need assessment for mentee needs at least, every 6 month. The need assessment must focus on hard-skill and soft-skills that mentee's need to be improved. The result of need assessment must be documented and report to Peer Mentor Supervisor. Report must be handover at least 5 days after held the assessment. The third task is to proposed development program for Mentee. After need assessment, Mentor should give a proposal to Mentor Supervisor about development program for Mentee. Mentor must conduct committee to design and run the program. Design program must be approved and monitoring by Supervisor. Evaluation must be held after run the program. Evaluation program report must approve by Supervisor at least, 5 days after program run. The fourth task is to motivate and encourage mentee to develop their hard-skills such as being active participate in class activity, always do their homework and task, focus with the lesson, etc; and develop their soft-skills, such as joining student organization, involved in extracurricular activities, joined any competitions, etc. The fifth task is Peer Mentor must explain to mentee about the university profile, the academic rule and system, etc. Peer Counselling to mentee if necessary will become an additional task for the Peer Mentor. The task of administration for the Peer Mentor is to report of student development progress every 3 month to Supervisor.

The specification for Peer Mentor's job are willing to do self-develop and having great commitment to participate actively in this program, proved by contract-signed. For the requirement is all student who study at University WM with second year, GPA > 3.00 of 4.00, and ever experience in any organization. 


\section{CONCLUSION}

Job analysis has been done to conduct proposal of job description and job specification for Peer Mentor and Duta WM as a Student Ambassador as the answer of research question. The output of this research result is the validated job analysis document. The document consists of job description, job specification for each job title. Job analysis that has been conducted must bring effect positively through the organization.

For future directions, research about effect of job analysis through the Duta WM as a Student Ambassador and Peer Mentor performance must be conduct. The process of job analysis document on this research are based on traditional process and just consisted of job description \& job specification only. For develop organization sustainly, try to develop and use job analysis based on competencies.

\section{REFERENCES}

Ali, H., \& Aroosiya. (2010). Impact of job design on employees' performance (with special reference to school teachers in the kalmunai zone). Journal of Management, 8 (1), 33-41

Armstrong, M. (2009). Armstrong's handbook of human resources management practice. New York: Kogan Page Limited.

Bangun, W. (2012). Manajemen sumber daya manusia. Jakarta: Penerbit Erlangga

Brannick, M. T., Levine, E. L. \& Morgeson, F. P. (2007). Job and Work Analysis: Methods, Research and Applications for Human Resource Management. Thousand Oaks, CA: Sage Publication.

Bratton, J., \& Gold, J. (2007). Human resource management: Theory and practise. Basingstoke: Palgrave Macmilan

Boulanger, J. (2013). Job analysis and job satisfaction. Thesis (unpublished). International Business Degree Program: Turku University of Applied Sciences. Retrieved from https://www.theseus.fi/bitstream/handle/10024/65583/Students_Julien\%20Boulanger.pdf?sequence

Bowin, R.B. \& Harvey, D. (2001). Human resource management: An experiential approach. Englewood Cliffs, NJ: Prentice Hall

Cascio, W.F. (1998). Applied psychology in human resource management (5thed). London: Prentice Hall International, Inc

Cascio, W. F. (1998). Managing human resources. Boston: Irwin/McGraw-Hill

Dessler, G. (2011). Human resource management (10th edition). Englewood Cliffs, New Jersey: Prentice Hall

Edian, A. G. A. (2015). Effects of job analysis on personnel innovation. International Journal of Business and Management Invention, 4 (10), 9-18

Fountain, J., \& Newcomer, K, E. (2016). Developing and sustaining faculty mentoring programs. Journal of Public Affairs Education. 22 (4), 483-506

I-Wei, C, \& Kleiner, B.H. (2002). How to conduct job analysis effectively. Management Research News, 25 (3), 73- 81 .

Kharabe, R \& Joseph, J. S. (2016). Job description, job analysis, its impact on productivity. International Journal of Commerce, Business and Management, 5 (5), 40-50

MačKayová, V. K., ZáVadská Z., \& M, Sirotiaková. (2010). Comparison of job analysis traditional and process approach. Human Resources Management \& Ergonomics. 4 (2), 1-16

Mangaleswaran, T., \& Kirushanthan, Kirthiga. (2015). Job description and job specification: A study of selected organizations in Sri Lanka. International Journal of Information Technology and Business Management. 41 (1), 30-36

Mathis, R. L dan Jackson, J. H. (2006). Human resources management (10th ed). New York: South-Western Educational Publishing

McKillip, J. (2001). Case studies in job analysis and training evaluation. International Journal of Training and Development, 5 (4), 283-289.

Mondy, R. W. (2010). Human resources management. New Jersey: Pearson Education, Inc. 
Nyasha, M, et al. (2013). Importance of establishing a job analysis exercise in an organization: A case study of bread manufacturing companies in zimbabwe. Australian Journal of Business and Management Research, $2(11), 35-42$.

Purhantara, W. (2010.) Metode penelitian kualitatitf untuk bisnis. Yogyakarta: Graha Ilmu

Raju, K., \& Banerjee, S. (2017). A study on job description and its effect on employee performance: Caase of some selected manufacturing organizations in the city of Pune, India. International Journal of Latest Technology in Engineering, Management \& Applied Science, VI (2), 1-10

Royer, (2009). Job Descriptions and Job Analyses in Practice: How Research and Application Differ. PhD Thesis, DePaul University, Chicago.

SHL Group. (2005). Guideline for best practise in the use of job analysis techniques. UK: The Pavilion. Retrieved from

https://static.squarespace.com/static/53df1c04e4b0fb8d41d4f6c0/t/542ac9a4e4b052f9013a8807/1412090 276704/Best-Practice-Job-Analysis.pdf

Siddique, C. M. (2004). Job analysis: A strategic human resources management practice. The International Journal of Human Resource Management, 15 (1), 219-244

Suthar, BK, et all. (2014). Impacts of job analysis on organizational Pperformance: An Inquiry on Indian Public Sector Enterprises. Procedia Economics and Finance, 11, 166 - 181

Truxillo, D.M., Paronto, M.E., Collins, M., \& Sulzer, J.L. (2004). Effects of subject matter expert viewpoint on job analysis results. Jornal Public Personnel Management, 33, 33-46 